BIOMEDICAL AND BIOSOCIAL ANTHROPOLOGY
$\begin{gathered}\text { Official Journal of the International Academy } \\ \text { of Integrative Anthropology } \\ \text { journal homepage: http://bba-journal.com }\end{gathered}$

\title{
Microscopic changes of the pancreas vessels in the dynamics after experimental thermal injury
}

\section{Zykova N. P.}

I. Horbachevsky Ternopil National Medical University, Ternopil, Ukraine

\section{ARTICLE INFO}

Received: 13 January 2021

Accepted: 16 February 2021

UDC: 616.37-091.8:616-001.17]-092.9

\section{CORRESPONDING AUTHOR}

e-mail: zykova@tdmu.edu.ua Zykova N.P.
The problem of burns is relevant in the world and in Ukraine. Thermal injury is not limited to local tissue changes, but causes significant morphofunctional disorders in the organs and systems of the affected organism, the result of this factor is a violation of blood supply to organs, including the pancreas. The aim of this work was to establish the histological condition of the vessels of the pancreas after experimental thermal injury. The experiments were performed on 40 adult white rats. Burns were applied under thiopental-sodium anesthesia with copper plates at a temperature of $96-97^{\circ}$ on the epilated surface of the skin of the back of animals for 15 seconds (the lesion area was $18-20 \%$ of the body surface). Decapitation of animals was performed on 1, 7, 14 and 21 days of the experiment. Pieces of the pancreas were taken for histological examination and processed according to generally accepted methods. Histological sections 5-6 $\mu \mathrm{m}$ thick were stained with hematoxylin-eosin, impregnated with silver by the Gordon-Sweets method, as well as staining by the tricolor method of MSB (ORB). Histological specimens were examined and documented using an SEO SCAN light microscope and a Vision CCD Camera. In the early stages of the experiment revealed a violation of the blood supply to the body. The lumens of most arteries were found to be dilated, and the wall thickness increased due to hypertrophy of the smooth muscle cells of the media. Leukocyte infiltration was determined in the perivascular spaces. The lumens of the small and middle veins were dilated and filled with blood, with parietal thrombi in some of them. Capillaries are characterized by a moderate expansion of their lumens, stasis. There was swelling of the paravasal spaces. Significant destructive-degenerative, inflammatory and sclerotic changes were observed in the later stages of the experiment. The walls of the vessels were moderately swollen. Smooth myocytes of the arterial media were hypertrophied, the cytoplasm was vacuolated, and contained pyknotically altered nuclei. Adventitia of vessels, especially veins, was swollen and fibrous. Occasionally there were violations of the wall of the components of the microcirculatory tract, which was accompanied by hemorrhage. There are single thrombosed vessels, spasmed arterioles, hemocapillaries with dilated lumens. The greatest changes, especially on the 21st day, were the adventitial membrane with the growth of collagen and reticular fibers. The blood supply to the vessels was moderate. Vessels of small diameter and hemomicrocirculatory tract were also significantly altered, their wall is deformed, thin, homogeneous. The lumens are dilated, with the formation of blood clots. Thus, in the early stages of the experiment there are adaptive-compensatory processes and initial destructive changes in the walls of the vessels of the organ, manifested by stasis, thrombosis, edema, deformation, infiltration of the wall and perivascular space. In the late period, significant destructive-degenerative changes in the structure of the walls of the vessels of the pancreas, accompanied by hemorrhage, inflammation, sclerosis of the wall and edema of the adventitia. These changes lead to a deterioration of blood supply and, consequently, a decrease in the functional activity of the body.

Keywords: burns, rats, pancreas, blood vessels.

\section{Introduction}

The problem of burns is relevant in the world and in Ukraine. According to the WHO definition, a burn is an injury to the skin or other tissues, caused mainly by exposure to high temperatures. Stable and fairly high mortality from 
burns leads to the recognition that the problem of thermal burns remains relevant today $[9,10,21,27,28,34,38]$. As a result, after a burn, the development of a burn disease is possible, which is accompanied by damage to all internal organs and systems of the body [1, 5, 7, 24]. Burn disease develops when $15-20 \%$ of the body surface is damaged, and its severity is determined by the area and depth of damage to the skin. Burn disease has a complex multicomponent pathogenesis, characterized by hypovolemia, circulatory disorders, especially microcirculation, severe intoxication and infection of the body, including the pancreas $[3,4,11,17,18$, $20,23,25,26,35]$.

The aim of the study was to establish histological changes in the components of the circulatory system of the pancreas in the dynamics of experimental thermal trauma.

\section{Materials and methods}

The experiments were performed on 40 adult white rats. The burn injury was reproduced according to the methodology developed at the Department of Histology and Embryology of I. Horbachevsky Ternopil National Medical University Ministry of Health of Ukraine. The burn was applied under thiopental-sodium anesthesia with copper plates heated in boiled water to a temperature of $97-100^{\circ} \mathrm{C}$ on the epilated surface of the skin of the animal's back for 15 seconds. Pieces of the pancreas were taken for microscopic examination on days 1, 7, 14, and 21 of the experiment. Pieces of the pancreas of experimental animals were placed in certain clamps depending on the method of study [8, 13].

The pieces were fixed in $10 \%$ formalin solution, then the pieces were dehydrated in alcohols of increasing concentration in a machine for histological treatment of AT4 tissues, poured into paraffin blocks. Sections obtained on a sled microtome MS-2 with a thickness of 4-5 $\mu \mathrm{m}$ were stained with hematoxylin and eosin. Impregnated with silver by the Gordon-Sweets method to detect basement membranes, reticular and immature collagen fibers, as well as staining by the tricolor method MSB (ORB) - an elective staining method for intravascular coagulation syndrome [8, 24]. Histological specimens were studied using an SEO CCAN light microscope and photodocumented using a Vision CCD Camera with an image output system from histological specimens.

\section{Results}

Conducted microscopic studies showed that on the 1st day of the experiment there was a violation of the blood supply to the pancreas. There was an expansion of the lumen of blood vessels, their fullness and thickening of the walls. The lumens of the large and middle arteries are moderately blood-filled and dilated. Swelling of all wall membranes was detected, but to the greatest extent, wall thickness increased due to hypertrophy of smooth muscle cells of the media (Fig. 1).

The lumens of the huge and middle veins were also

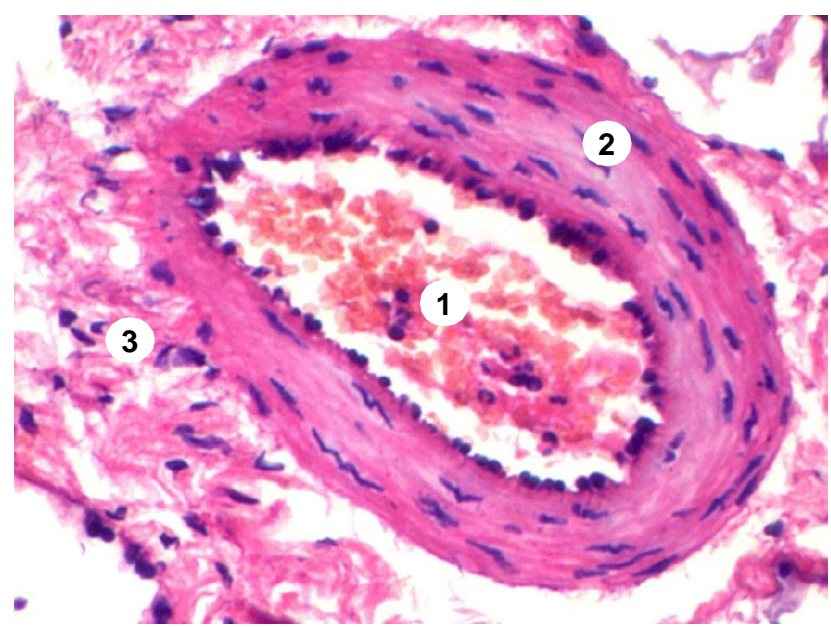

Fig. 1. Microscopic changes of the artery for 1 day after thermal injury. 1 - blood-filled lumen of the vessel, 2 - smooth myocytes of the media, 3 - edema of the adventitia. Staining with hematoxylin and eosin. x200.

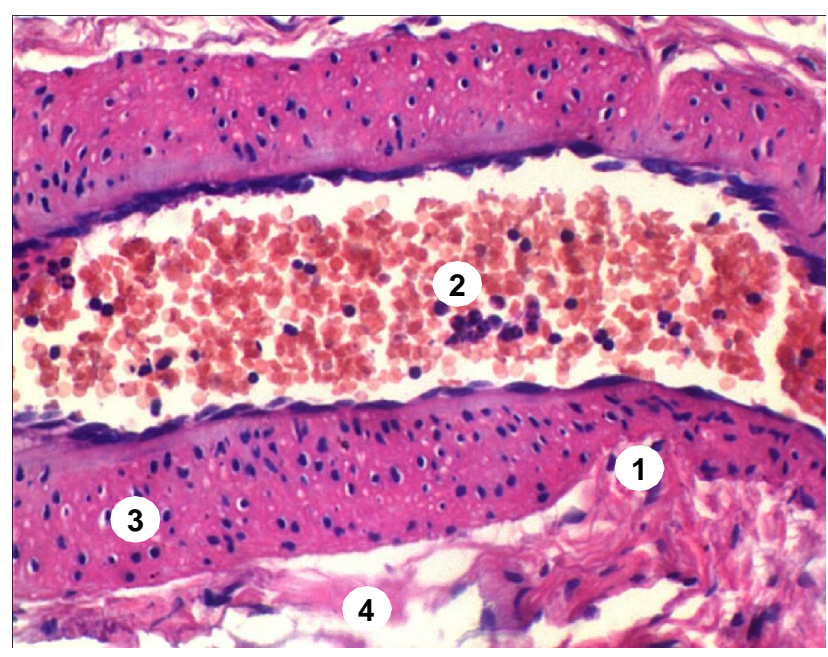

Fig. 2. Microscopic changes of the artery on the 7th day after thermal injury. 1 - partial deformation and dystonia of the wall, 2 shaped elements of blood in the lumen of the vessel, 3 - destructively altered smooth myocytes of the media, 4 - edema and delayed adventitia. Staining with hematoxylin and eosin. x200.

dilated and filled with blood, there was swelling of the perivascular spaces, there was a slight leukocyte infiltration of the adventitia. Arterioles had a narrowed, blood-filled lumen, a slight thickening of the wall. Due to the spasm of the arteriole wall, their capacity was reduced. In the hemocapillaries, dilation of the lumens and their sharp blood supply, existing stasis and sludge effect of erythrocytes were observed. The endothelium looked swollen, as a result of which its protrusion into the lumen of the vessels was observed.

After 7 days, an increase in alternative changes of vessels, which had an adaptive-compensatory character, was detected. There was a partial deformation of the wall of arteries of small and medium diameter, an increase in the thickness of the media due to hypertrophy and reduction 

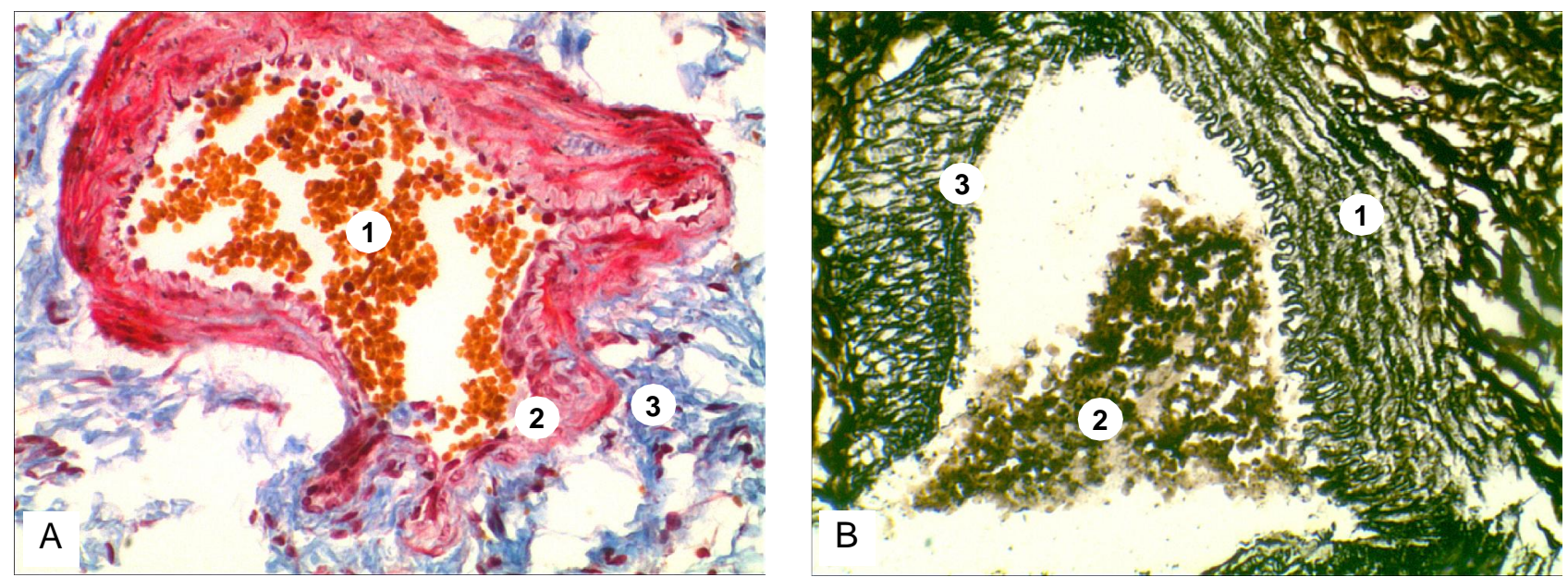

Fig. 3. Microscopic changes of vessels on the 14th day after burn injury. A. Artery of large diameter. 1 - blood-filled lumen, 2 - deformation and destruction of the wall, 3 - edema and infiltration of the adventitia. Staining by MSB (JAG). x200. B. Artery of large diameter. 1 collagen and reticular fibers of the vessel wall, 2 - shaped elements in the lumen, 3 - violation of the tortuosity of the inner elastic membrane. Gordon-Sweets staining. x200.

of smooth myocytes, hyperchromic nuclei, edematous, moderate leukocyte infiltration. Perivascular edema and disorganization of connective tissue elements of adventitia were also observed. The lumens of the arteries remained blood-filled (Fig. 2).

The lumen of the venous vessels remained dilated and blood-filled, and their wall was characterized by destruction of the muscular membrane, edema of the perivascular spaces, leukocyte infiltration, to the greatest extent, the adventitial membrane. Among the arterial and venous units, vessels with the phenomenon of dystonia were observed, which was manifested by alternation of thickened and thinned sections of the vessel wall and deformation of their lumen. The vessels of a hemomicrocirculatory channel which were characterized by the stagnant phenomena in a gleam, thickening, hypostasis and destruction of a wall underwent the greatest changes, parietal thrombi were observed. However, vessels with thinned walls and sagging lumens were found. The lumens of most hemocapillaries are excessively dilated and blood-filled, perivascular edema was detected. Capillaries with obliterated lumen were noted in some places. Uneven protrusion of endothelial cell nuclei into the vascular lumen was observed, the basement membrane was indistinctly contoured.

Microscopically on the 14th day there was a significant remodeling of the vascular wall with increasing destructive changes, compared with the previous term. Most arteries (regardless of diameter) had a blood-filled deformed lumen and were characterized by moderate edema of the wall thickening of the middle membrane due to smooth muscle elements and the initial signs of adventitial sclerosis, associated with increased activity of fibroblasts producing fibrous components of intercellular spaces. Smooth myocytes of the arterial media are hypertrophied, the cytoplasm is vacuolated, swollen, enlightened, and contains pyknotically altered nuclei. The intima of the vessels was also destroyed, the protrusion of endothelial cell nuclei into the lumen of the vessels was determined, sometimes their desquamation. The inner elastic membrane of the intima was swollen, thickened, in some areas homogeneous, blurred, fuzzy. Focal extravasal hemorrhages with violation of vascular integrity were determined (Fig. 3).

The venous part of the vascular bed at this time was characterized by moderate wall edema, compared with previous terms, thinning or hypertrophy of the media, sclerosis of the adventitia, which was manifested by the growth of collagen and reticular fibers. Large extravascular clusters of leukocytes were detected. Most hemocapillaries had large, blood-filled lumens with destructively altered erythrocytes, thrombosis, histoleukocyte infiltration of the paravasal spaces. The cells of the lumenal areas of the plasmalemma are swollen with fuzzy contours, the nucleus is elongated. In some places there was a violation of the vascular wall of the hemomicrocirculatory tract, which was accompanied by hemorrhages.

At day 21 , histological changes were characterized by significant destructive-degenerative, inflammatory and sclerotic changes in the structural components of the walls of arterial and venous vessels. The blood supply to the vessels is moderate, their wall is destructively changed, which is manifested by thinning, thickening, leukocyte infiltration and significant sclerosis of the intima, media and, to the greatest extent, adventitia with complete obliteration of the lumen. It has been established that vessels of large and medium diameter are characterized by moderate blood supply, thickening of their wall due to leukocyte infiltration, hypertrophy of the muscular membrane, complete sclerosis, mainly adventitia. Vessels of small diameter with hypertrophied media, complete sclerosis of the wall and obliteration of the lumen (Fig. 4). 

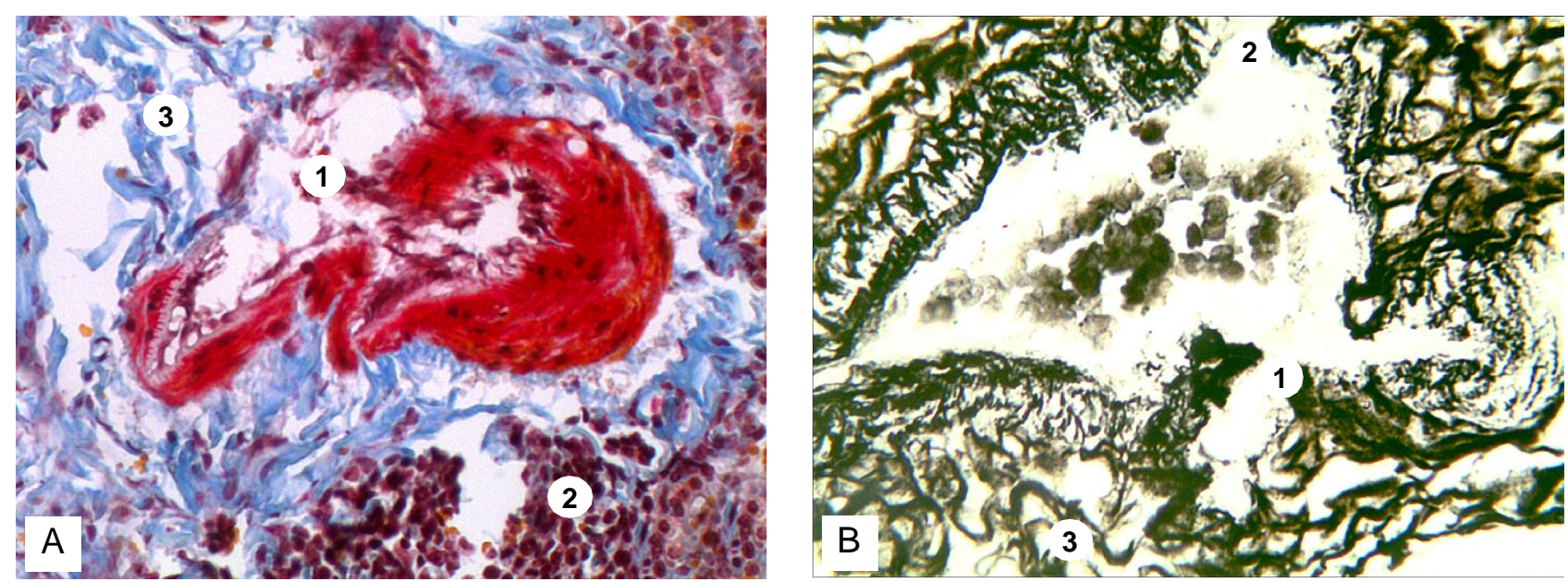

Fig. 4. Microscopic changes of vessels for 21 days after burn injury. A. Artery of medium diameter. 1 - dystonia and wall fragmentation, 2 - leukocyte infiltrates of the adventitia, 3 - edema and defloration of the adventitia. Staining by MSB (ORB). x200. B. Vein of medium diameter. 1 - destruction and fragmentation of the wall, 2 - deformed lumen, 3 - sclerosis of the wall. Gordon-Sweets staining. x400.

Most vessels of the microcirculatory tract were characterized by moderate blood supply, edema of smooth muscle tissue, with partial atrophy of myocytes, complete sclerosis of the intima, media and adventitia, accompanied by the growth of collagen and reticular fibers. The lumens of some hemocapillaries are dilated, blood-filled with the formation of blood clots, but most capillaries had a narrow lumen, their wall is deformed, thin, homogeneous. Detachment of the endothelium from a homogeneous, indistinctly contoured, thickened basement membrane was observed. Perivascular leukocyte infiltration, sometimes diapedetic hemorrhages, with formation of inflammatory infiltrates are found.

\section{Discussion}

Structural changes of the pancreas, in particular, the vascular bed, as a reaction to the pathological process in the body, regardless of its origin, attracts attention, mainly due to the involvement of the gland in endocrine and exocrine function [3, 4]. At disturbance of blood circulation, the morphological changes which are followed by hypotoxic changes which become rather defining in functional ability of organ grow. Vessels of the hemomicrocirculatory tract play an important role in the regulation of blood flow and outflow from the organ, tissue perfusion [7, 37, 39].

A significant amount of scientific work is devoted to the study of microscopic changes in the pancreas, both organs and its individual components, in particular the bloodstream. The structural organization of blood vessels corresponded to the data described in the literature on the peculiarities of their structure in white rats, other animals and humans [6, 17, 25].

According to the results of the study of the vascular bed of the pancreas in the simulation of hypertension [32] found that age-related changes in the arterial link of rats in normal and in the simulation of trauma, showed an interdependence between rat age and trauma, manifested in decreased vascular lumen, endothelial damage, remodeling of the walls, which leads to a violation of vascular capacity. Other authors [21] studied the state of the bloodstream during dehydration of the body, and showed that destructive changes in the microcirculatory tract do not depend on the duration of the experiment, but progress depending on the severity of dehydration. The results of studies in hypothermia of the pancreas [2, 15, 29, 30, 33], showed that superficial and shallow hypothermia did not cause significant morphological changes in the bloodstream, but with increasing duration of hypothermia caused more significant changes. Capillaries and veins are sharply filled with swollen walls, dilated lumen, the formation of a "sludge" effect. Most of these data are consistent with the results of our research. According to the results of research, the effect of heavy metals $[14,16,36]$ on the gland in 30-, 60-, and 90-day terms was observed by dilation and edema of blood vessel walls and their overflow with blood, intense lymphohistocytic inflammatory infiltration, growth of connective tissue elements forming "fields" of sclerosis, which is identified with the results of our research. The study of the effect of narcotic substances [19, 22, 31] on the vessels of the pancreas had a similar character, which was manifested by edema, infiltration and profound destructive changes in blood vessels.

Thus, the results of our own research and data from the scientific literature indicate that due to the action of various exogenous factors and stressors on the body of experimental animals develop changes in the arterial and venous vascular bed and vascular links of the hemomicrocirculatory tract.

Further studies are planned to determine the structural changes in the components of the blood vessels of the pancreas after severe thermal trauma to the skin and under conditions of correction.

\section{Conclusion}

Histological examinations of pancreatic vessels after experimental thermal trauma revealed that in the early stages 
of the experiment there are adaptive-compensatory processes and initial destructive changes in the walls of vascular organs, manifested by stasis, thrombosis, edema, deformity, infiltration of the wall and perivascular space. In the late period, significant destructive-degenerative changes

\section{References}

[1] Ahmad, A., Herndon D. N., \& Szabo C. (2019). Oxandrolone protects against the development of multiorgan failure, modulates the systemic inflammatory response and promotes wound healing during burn injury. Burns, 45(3), 671-681. doi: 10.1016/j.burns.2018.10.006

[2] Doroshkevych, S. V., Pyvchenko, P. G., \& Doroshkevich, E. Y. (2010). Опыт криомоделирования патологии поджелудочной железы [Experience in cryomodelling pancreatic pathology]. Экспериментальная и клиническая гастроэнтнрология - Experimental and Clinical Gastroenterology, (8), 52-55.

[3] Elbassuoni, E. A., \& Abdel Hafez, S. M. (2019). Impact of chronic exercise on counteracting chronic stress-induced functional and morphological pancreatic changes in male albino rats. Cell Stress Chaperones, 24(3), 567-580. doi: 10.1007/s12192019-00988

[4] Galunko, G. M. (2017). Histological changes in the small intestine in the advanced stages of burn disease. World of Medicine and Biology, 3(61), 90-96. doi: 10.26724/2079-8334-2017-361-90-96

[5] Ghodsi, Z., Barzegar, A., \& Salamati, P. (2020). Mechanism classification of fatal injuries. Burns, 46(2), 492-493. doi: 10.1016/j.burns.2019.01.015

[6] Gushchin, Ya., Shedko, V., Muzhikyan, A., Makarova, M., \& Makarov, V. (2018). Сравнительная морфология поджелудочной железы экспериментальных животных и человека [Comparative morphology of the pancreas of experimental animals and humans]. Лабораторные животные для научных исследований - Laboratory Animals for Science, (3), 33-48.

[7] Hew, J., Parungao, R., Shi, H., Tsai, K., Kim, S., Ma, D., ... \& Wang, Y. (2020). Mouse models in burns research: Characterisation of the hypermetabolic response to burn injury. Burns, 46(3), 663-674. doi: 10.1016/j.burns.2019.09.014

[8] Horalskyi, L. P., Khomych, V. T., \& Kononskyi, O. I. (2005). Основи гістологічної техніки та морфоорункціональних методів дослідження в нормі та при патології [Fundamentals of histological technique and morphofunctionalmethods of research in normal and pathology]. Державний агроекологічний університет - State Agroecological University. Житомир: Полісся - Zhytomyr: Polissya.

[9] Janak, J. C., Clemens, M. S., Howard, J. T., Le, T. D., Cancio, L. C., Chung, K. K., ... \& Stewart, I. J. (2018). Using the injury severity score to adjust for comorbid trauma may be double counting burns: implications for burn research. Burns, 44(8), 1920-1929. doi: 10.1016/j.burns.2018.03.012

[10] Jeschke, M. G., van Baar, M. E., Choudhry, M. A., Chung, K. K., Gibran, N. S., \& Logsetty, S. (2020). Burn injury. Nature Reviews Disease Primers, 6(1), 1-25. doi: 10.1038/s41572-020-01455

[11] Kearney, L., Francis, E. C., \& Clover, A. J. (2018). New technologies in global burn care - a review of recent advances. Int. J. Burns Trauma, 8(4), 77-87. PMID: 30245912

[12] Kovchun, V. Yu., Sikora, V. Z., Lindin, M. S., \& Sikora, V. V. (2020). Гістоморфометрична оцінка змін підшлункової за- in the structure of the walls of the vessels of the pancreas, accompanied by hemorrhage, inflammation, sclerosis of the wall and edema of the adventitia are found. These changes lead to a deterioration of blood supply and, consequently, a decrease in the functional activity of the organ.

лози за умов гіперосмолярної дегідратації [Histomorphometric assessment of changes in the parenchyma of the pancreas under the influence of hyperosmolar dehydration]. Буковинський медичний вісник - Bukovynian Medical Bulletin, 24(2), 52-56. doi: 10.24061/ 2413-0737.XXIV.2.94.2020.43

[13] Kozhemyakin, Yu. M., Chromov, O. S., \& Filonenko, M. A. (2017). Науково-практичні рекомендації з утримання лабораторних тварин та роботи з ними [Scientific and practical recommendations for the care and use of laboratory animals]. Київ: Інтерсервіс - Kiev: Interservis.

[14] Kravets, O. V. (2009). Динаміка морфологічних та морфометричних змін підшлункової залози за умов техногенних мікроелементозів [Dynamics of morphological and morphometric changes of the pancreas under the conditions of technogenic microelementosis]. Вісник морфрології Reports of Morphology, 15(1), 4-7.

[15] Kurzanov, A. N., Zabolotskikh, N. V., Myasnikova, V. V., \& Shestopalov, A. V. (2016). Патофизиологические аспекты экспериментального криомоделирования патологических состояний поджелудочной железы [Pathophysiological aspects of experimental cryomodeling of pathological conditions of the pancreas]. Кубанский научный медицинский весник - Kuban scientific medical journal, 6(116), 97100.

[16] Lebedev, S. V., Gavrish, I. A., \& Gubaydullina, I. Z. (2019). Морфо-биохимические показатели и активность пищеварительных ферментов у крыс линии wistar под влиянием различных источников хрома [Different chrome sources influence on morphobiochemical indicators and activity of digestive enzymes in wistar rats]. Сельскохозяйственная биология - Agricultural biology, 54(2), 304-315. doi: 10.15389/agrobiology.2019.2.304rus

[17] Maden, M. (2018). Optimal skin regeneration after full thickness thermal burn injury in the spiny mouse. Acomys cahirinus. Burns, 44(6), 1509-1520. doi: 10.1016/j.burns.2018.05.018

[18] Mohapatra, S., Majumder, S., Smyrk, T. C., Zhang, L., Matveyenko, A., Kudva, Y. C., \& Chari, S. T. (2016). Diabetes mellitus is associated with an exocrine pancreatopathy: conclusions from a review of literature. Pancreas, 45(8), 11041110. doi: 10.1097/MPA.0000000000000609

[19] Mykhalevych, М. М. (2019). Морфологічні зміни органів за впливу опіоїдів [Morphological changes of organs under the influence of opioid]. Клінічна анатомія та оперативна хірургія - Clinical anatomy and operative surgery, 18(4), 133145. doi: 10.24061/1727-0847.18.4.2019.21

[20] Nahaichuk, V. I., Khimich, S. D., Zheliba, M. D., Zhuchenko, O. P., Povoroznyk, A. M., Prysiazhniuk, M. B., \& Chornopyshchuk, R. М. (2017). Сучасні технології лікування хворих з критичними та надкритичними опіками [Modern technologies of treatment of patients with critical and supravithic burns]. Вісник Вінницького національного медичного унівеситеmy - Reports of Vinnytsia National Medical University, 2(21), 428-433.

[21] Nielson, C. B., Duethman, N. C., Howard, J. M., Moncure, M., \& Wood, J. G. (2017). Burns: Pathophysiology of systemic 
complications and current management. J Burn Care Res, 38(1), e469-e481. doi: 10.1097/BCR.0000000000000355

[22] Popyk, Р. М. (2014). Особливості мікроструктури підшлункової залози білого щура за умов впливу опіоїду [Microstructure characteristics of pancreas white rat under influence opioid]. Вісник проблем біології і медицини Bulletin of problems of biology and medicine, 2(3), 310-313.

[23] Porter, C., Tompkins, R. G., Finnerty, C. C., Sidossis, L. S., Suman, O. E., \& Herndon, D. N., (2016). The metabolic stress response to burn trauma: current understanding and therapies. Lancet, 388(10052), 1417-1426. doi: 10.1016/S01406736(16)31469-6

[24] Protsenko, O. S., Shapoval, O. V., Teslenko, A. O., Rodionov, M. O., Voshylin, B. R., \& Yeletskyi, M. S. (2019). Клінічні та експериментальні дослідження тканин при термічних пошкодженнях [Clinical and experimental studies of tissues in thermal injuries]. Актуальні проблеми сучасної медицини Actual problems of modern medicine, (3), 4-13.

[25] Quesada, R., Simon, C., Radosevic, A., Poves, I, Grande, L., \& Burdio, F. (2019). Morphological changes of the pancreas after pancreaticoduodenectomy. Scientific Reports, 9(1), 14517. doi: 10.1038/s41598-019-51173-1

[26] Rae, L., Fidler, P., \& Gibran, N. (2016). The physiologic basis of burn shock and the need for aggressive fluid resuscitation. Critical Care Clinics, 32(4), 491-505. doi: 10.1016/ j.ccc.2016.06.001

[27] Roshangar, L., Soleimani Rad, J., Kheirjou, R., Reza Ranjkesh, M., \& Ferdowsi Khosroshahi, A. (2019). Skin burns: Review of molecular mechanisms and therapeutic approaches. Wounds, 31(12), 308-315. doi: 10.1038/s41572-020-0145-5

[28] Ryan, C. M, Parry, I., \& Richard, R. (2017). Functional Outcomes Following Burn Injury. Journal of Burn Care \& Research, 38(3), e614-e617. doi: 10.1097/bcr.0000000000000537

[29] Savishchev, A. V. (2010). Электронно-микроскопическая характеристика поджелудочной железы при изменении температурного режима [Electron-microscopic characteristics of the pancreas with a change in temperature]. Известия высших учебных заведений. Поволжский регион. Медицинские науки - Proceedings of higher educational institutions. Volga region. Medical sciences, 4(16), 11-17.

[30] Savishchev, A. V., \& Moldavskaya, A. A. (2011). Морфоогенез поджелудочной железы на этапах онтогенеза при экспериментальном моделировании под воздействием стрессогенных фракторов [Pancreatic morphogenesis at the stages of ontogenesis in experimental modeling under the influence of stress factors]. Астрахань-Москва Astrakhan-Moscow.

[31] Shabdarbaeva, D. M, Sayakenov, N. B., Alimbekova, B. R., \& Lepesbaev, M. N. (2015). Иммуноморфологическая характеристика поджелудочной железы при действии на организм наркотических веществ [Immunomorphological characteristics of the pancreas when exposed to drugs]. Современная медицина: актуальные вопросы - Modern medicine: current issues, 2(38), 90-102.

[32] Shulhai, A. H., \& Mokra, A. P. (2015). Морфометрична характеристика кровоносного русла підшлункової залози при гіпертензії у малому колі кровообігу [Morphometric description of pancreatic blood channels with underlying lesser circuit hypertension]. Шпитальна Хірургія. Журнал імені Л. Я. Ковальчука - Hospital Surgery. Magazine named after L. Ya. Kovalchuk, (4), 16-19.

[33] Stepanyan, Yu. S. (2008). Морфофрункциональные эквиваленты реакции поджелудочной железы на гипотермию [Morphofunctional equivalents of reaction pancreas on general overcooling]. Проблемы экспертизы в медицине - Problems of expertise in medicine, (2), 22-24.

[34] Tapking, C., Boson, A. L., Rontoyann, V. G., Hundeshagen, G., Kowalewski, K. F., Popp, D., ... \& Branski, L. K. (2020). A systematic review and meta-analysis of 30-day readmission rates following burns. Burns, 46(5), 1013-1020. doi: 10.1016/ j.burns.2019.11.001

[35] Tosti, L., Hang, Y., Debnath, O., Tiesmeyer, S., Trefzer, T., Steiger, K., ... \& Conrad, C. (2020). Single-nucleus and in situ RNA-sequencing reveal cell topographies in the human pancreas. Gastroenterology, 160(4), 1330-1344. doi: 10.1053/ j.gastro.2020.11.010

[36] Vorontsova, Z. A., \& Gureev, A. S. (2013). Биоэффректы экзокринной и эндокринной паренхимы органов на обедненный уран [Biotffects exocrine and endocrine parenchyma organs on depleted uranium]. Health \& education millennium, 15(1-4), 250-252.

[37] Whitcomb, D. C., Frulloni, L., Garg, P., Greer, J. B., Schneider, A., Yadav, D., \& Shimosegawa, T. (2016). Chronic pancreatitis: an international draft consensus proposal for a new mechanistic definition. Pancreatology, 16(2), 218-24. doi: 10.1016/j.pan.2016.02.001

[38] Young, A. W., Graves, C., Kowalske, K. J., Perry, D. A., Ryan, C. M., Sheridan. R. L., ... \& Palmieri, T. (2017). Guideline for Burn Care Under Austere Conditions: Special Care Topics. J Burn Care, 38(2), e497-e509. doi: 10.1097/ BCR.0000000000000369

[39] Zinenko, D. Yu., \& Tverdokhlib, I. V. (2020). Ультраструктурна характеристика гемомікроциркуляторного русла та паренхіматозно-стромальних елементів підшлункової залози та печінки в моделі гострого панкреатиту з використанням різних доз таурохолату натрію [Ultrastructural characteristics of the hemomicrocirculatory bed and parenchymatous-stromal elements of the pancreas and liver in a model of acute pancreatitis using different doses of sodium taurocholate]. Морфоологія - Morphologia, 14(1), 23-34. doi: 10.26641/1997-9665.2020.1.23-34 